\title{
Reproductive biology of the island grouper (Mycteroperca fusca) in the Canary Islands, northwest coast of Africa
}

\author{
ROCÍO BUSTOS, ÁNGEL LUQUE and JOSÉ G. PAJUELO \\ Departamento de Biología, Universidad de Las Palmas de Gran Canaria, Campus de Tafira, \\ 35017 Las Palmas de Gran Canaria, Spain. E-mail: jpajuelo@dbio.ulpgc.es
}

\begin{abstract}
SUMMARY: This is the first time that the reproductive characteristics of Mycteroperca fusca have been analyzed over the whole area of its distribution, using the parameter of the histological analysis of the gonads. This species is a protogynous hermaphrodite with a marked predominance of females (1:4.9). The males and females displayed marked differences in the distribution of the sizes. The females were distributed over all the size ranges analyzed (229-725 mm total length), whereas the males were observed within the larger sizes, as of $428 \mathrm{~mm}$. One transitional specimen $(610 \mathrm{~mm}$ total length) was observed. The size at which the females first reached sexual maturity was $335 \mathrm{~mm}$ total length whereas the size at which $95 \%$ of females reached sexual maturity was $398 \mathrm{~mm}$ total length. The average size at which $50 \%$ of the females had inverted to the male condition was found to be $678 \mathrm{~mm}$ total length. The range of sizes at which the process of sexual inversion took place was broad, between 428 and $725 \mathrm{~mm}$ total length. The reproductive period was long, almost covering the annual cycle, although the maximum activity was observed between April and October, with a peak in spawning in June-July.
\end{abstract}

Keywords: Mycteroperca fusca, island grouper, sex change, maturity, spawning.

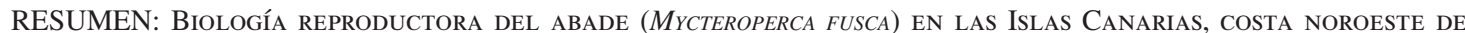
ÁFRICA . - Este es el primer estudio que aborda las características reproductoras de Mycteroperca fusca, en toda su área de distribución, utilizando el estudio histológico de las gónadas. La especie se caracteriza por un hermafroditismo proterogínico. Existe una marcada predominancia de las hembras (1:4.9). Los machos y las hembras muestran marcadas diferencias en la estructura de tallas. Las hembras se distribuyen en todo el rango de tallas analizado (229-725 mm de longitud total) mientras que los machos sólo fueron observados en las tallas superiores, por encima de los $428 \mathrm{~mm}$ de longitud total. Se analizó un ejemplar intersexual de $610 \mathrm{~mm}$ de longitud total. La talla a la cual las hembras alcanzan la madurez sexual es $335 \mathrm{~mm}$ de longitud total, mientras que la talla a la cual el $95 \%$ de las hembras se consideran maduras es $398 \mathrm{~mm}$ de longitud total. La talla media a la cual el $50 \%$ de las hembras han invertido a la condición de macho fue $678 \mathrm{~mm}$ de longitud total. El rango de tallas en el que el proceso de inversión sexual tiene lugar es amplio, entre 428 y $725 \mathrm{~mm}$ de longitud total. El periodo reproductivo es amplio, cubriendo casi el ciclo anual completo, aunque el máximo de actividad se localiza entre los meses de abril y octubre, con un máximo de puesta en junio-julio.

Palabras clave: Mycteroperca fusca, abade, inversión sexual, madurez, puesta.

\section{INTRODUCTION}

The large species of the Serranidae family are generally of great importance in marine ecosystems, and play a basic role in the food chain since they are often the main predators of the ecosystems into which they are integrated. In the Serranidae family, the genus Mycteroperca, at present represented by 15 different species, is characterized by the large size of individuals (Heemstra and Randall, 1999). The main characteristics of the life cycle of most of these species are well known, given the high level of fishing interest in their areas of distribution (Heemstra and Randall, 1999). However, in the case of Mycteroperca fusca (Lowe, 1836), despite the ecological and fishing interests in the Atlantic waters around the islands of Madeira, the 
Azores, the Savage Islands, the Canary Islands and Cape Verde, there is no information whatsoever with respect to the characteristics of its life cycle. This is because for many years $M$. fusca was confused with Mycteroperca rubra (Bloch, 1793), until Heemstra (1991) established that the species found in the Macaronesian region was $M$. fusca, with the distribution of M. rubra limited to the west coast of Africa and Mediterranean waters.

In the Canary Islands, as is the case with most of the large serranids, M. fusca is found on rocky and sandy-rocky sea-beds from the shore down to a depth of $150 \mathrm{~m}$ and is most frequent in dips and bays, where it swims around large rocks at mid-depths, most frequently alone but sometimes in small shoals (Bustos, 2009). The current state of its populations is directly linked to the degree of human pressure on the species (Tuya et al., 2005). In the Canary Islands, where fishing has been developed intensively, the populations are near to collapse and total landings of this species have decreased by approximately $95 \%$ over the last fifty years (Bustos, 2009). Traditionally, the most sought-after individuals have corresponded to those of greatest size $(>600 \mathrm{~mm})$, although currently the sizes which make up the catch are between 300 and $500 \mathrm{~mm}$. The records of on-site observation of the same xanthic specimens over more than thirty years in the waters of Madeira confirm that this species can live for more than 30 years (Weitz, pers. comm.). In the past, samples of larger specimens recorded in the Canaries have reached at least $860 \mathrm{~mm}$ in total length, which would correspond to ages of nearly 40 years. No bag limits are currently imposed on its fishery and only a minimum size legislation $(350 \mathrm{~mm})$ has been implemented as a management strategy.

The absence of available data on the biology of this species is particularly worrying if we consider that the correct management of biological resources should be based on the most complete information possible with respect to the ecology of the species involved. The objective of the present study was to establish the pattern of sexual development of the species, and to determine its main reproductive characteristics in the Canary Islands. This information is essential for the proper management of the species in this area.

\section{MATERIALS AND METHODS}

A total of 214 specimens of $M$. fusca were analyzed between January 2004 and December 2005. The samples were collected from the small-scale fishery on the islands of Fuerteventura and Gran Canaria (Canary Islands, northwest coast of Africa).

The total length, TL $(\mathrm{mm})$ and the total mass TM $(\mathrm{g})$, and gonad mass GM (0.01 g) were taken for each fish. Unless otherwise indicated, all lengths reported are total length. All gonads were also fixed and preserved in $4 \%$ buffered formaldehyde and subsequently processed histologically. Slices of tissue were embed- ded in paraffin, sectioned at $5 \mu \mathrm{m}$ and stained with Harris haematoxylin followed by eosin counter stain. Sectioned and stained tissue was subsequently examined under a light microscope. The sex and the maturation stage were determined from the histological sections. Fish were identified as females, males or in transition from female to male following Sadovy and Shapiro (1987) and Brulé et al. (2003a,b). Using the sexual classes as defined by Brulé et al. (1999) specifically for Mycteroperca species, and applied extensively as criteria in groupers (Shapiro et al., 1993; Sadovy and Colin, 1995; Brulé et al., 2003 a,b; Tuz-Sulub et al., 2006), adults were classified as resting, ripening, ripe and running, or spent (covering both spent and recovering ovaries). The growing oocytes were classified according to the six histological stages proposed by Moe (1969) specifically for groupers, modified by Brulé et al. (1999) for Mycteroperca species and extensively used for this genus (Brulé et al., 2003a, b; Tuz-Sulub et al., 2006): I, primary oocyte; II, immature oocyte; III, oocyte in primary vitellogenesis; IV, oocyte in early secondary vitellogenesis; $\mathrm{V}$, oocyte in late secondary vitellogenesis; VI, mature and hyaline oocyte. The criteria described by Shapiro et al. (1993) for grouper and by Brulé et al. (2003b) for Mycteroperca species, and extensively applied as criteria in grouper species (Sadovy and Colin, 1995; Rhodes and Sadovy, 2002), were used to distinguish a resting mature female from an immature female based on the presence of muscle bundles remnants and connective tissue surrounding blood vessels. Testes were classified according to the most advanced stage of spermatogenesis observed. The spermatogenesis was classified under four histological categories: spermatogonium, spermatocyte, spermatid and spermatozoa, based on a modified criteria of Brulé et al. (2003b). Males were classified by the presence or absence and relative proportions of germinal stages, in conjunction with structural aspects of the gonad.

Difference in mean total length between sexes was tested using a t-test. The Kolmogorov-Smirnov nonparametric Z-test was used to analyze the differences in the range of male and female sizes (Sokal and Rohlf, 1995).

The proportion of the sexes (males to females) was estimated as a total and by size intervals. Sex ratios were tested statistically for significant deviations from the expected 1:1 ratio with a Pearson chi-square goodness-of-fit test $(\alpha=0.05)$ (Sokal and Rohlf, 1995).

The reproductive period was defined for both sexes using the relative proportion of animals in each sexual stage and by examining seasonal variations in the gonadosomatic index (GSI=100GM/TM) (Brulé et al., 2003b).

Length-at-sexual maturity of female, length at which 50\% of the specimens had become mature (L50), was estimated by fitting a logistic ogive:

$$
P=\frac{100}{1+e^{-r\left(L_{t}-L_{50}\right)}}
$$


where $\mathrm{P}$ is the percentage of mature fish at length TL and $\mathrm{r}$ is the model parameter (Crabtree and Bullock, 1998; Brulé et al., 1999, 2003a, b). The size at which $50 \%$ of the females reverted to male (P50) was also determined by fitting a logistic ogive (Crabtree and Bullock, 1998; Brulé et al., 1999, 2003a, b). The functions were fitted to data by means of LevenbergMarquardt's algorithm for non-linear least squares parameter estimation. On the basis of this analysis, females were considered to be mature at the sexual stages resting mature, ripening, ripe and running, or spent, as recommended by Brulé et al. (2003a,b) for Mycteroperca species. Following the criteria given by Shapiro (1984), the range of sizes and average sizes at which the process of sexual reversal takes place were calculated, together with the percentage of maximum $\mathrm{TL}$ at first maturity. The range of overlap in the sizes of the males and the females divided by the length of the largest sampled island grouper was used to analyze the variation in size during sexual reversal (Shapiro, 1984).

The following criteria, as established by Sadovy and Shapiro (1987), were used to identify the sequence of hermaphroditism: membrane-lined central cavities in the testicles, transitional individuals, unovulated yolk ova in stage 1, 2 or 3, oocytic atresia within testes, and sperm sinuses in the gonadal wall.

\section{RESULTS}

Of the 214 histologically sexed specimens, 36 were males and 177 females. One transitional individual (610 mm TL) was observed histologically. Fish varied in size from 229 to $745 \mathrm{~mm}$ TL. Males varied from 428 to $745 \mathrm{~mm}$ TL. Female TL varied between 229 and $725 \mathrm{~mm}$. In mature females (resting mature, ripening, ripe and running, and spent) total length varied from 310 to 725 TL. Males were only observed in the larger size categories (Fig. 1), with a significant difference in mean TL between mature females $(470 \mathrm{~mm})$ and males $(559 \mathrm{~mm})\left(\mathrm{t}\right.$-test, $\left.\mathrm{t}=4.4>\mathrm{t}_{0.05,158}=1.9, \mathrm{P}=0.001\right)$. The size range of the mature females and males analyzed differed significantly (Kolmogorov-Smirnov $\mathrm{Z}$ non-parametric test; $\mathrm{Z}=2.4 \mathrm{n}=158, \mathrm{P}=0.0001$ ). The overall sex ratio was 1:4.9, diverging significantly from 1:1 (Pearson $\chi^{2}$ test; $\chi^{2}=93.4>\chi_{\mathrm{t}}^{2} 1,0.05=3.8, \mathrm{n}=213, \mathrm{P}=0.0001$ ). The overall sex ratio of males to mature females was 1:3.4, diverging significantly from $1: 1$ (Pearson $\chi^{2}$ test; $\left.\chi^{2}=45.4>\chi_{\mathrm{t} 1,0.05}^{2}=3.8, \mathrm{n}=158, \mathrm{P}=0.0001\right)$.

The proportion of the sexual stages for females and males varied by season (Fig. 2). Females in the ripening state were observed between February and October (Fig. 2a). Their ovaries were characterized by oocytes in primary vitellogenesis $(150-200 \mu \mathrm{m})$ and oocytes in early secondary vitellogenesis $(250 \mu \mathrm{m})$ (Fig. 3c). Ripe and running females were observed between April and October (Fig. 2a), and were characterized by the presence of oocytes in late secondary vitellogenesis (350 $\mu \mathrm{m})$ and mature oocytes $(400-500 \mu \mathrm{m})$ (Fig. 3d,e).

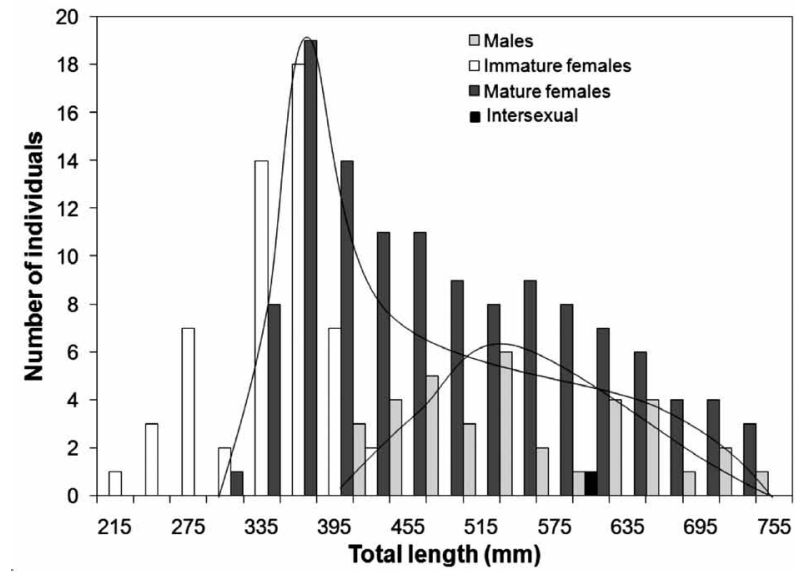

FIG. 1. - Size-frequency distribution in number of fish for males and females of Mycteroperca fusca caught between January 2004 and December 2005 in waters of the Canary Islands.

Females in the spent stage, with massive atresia, were mainly observed between May and December (Fig. 2a). Atretic oocytes were also found in the ovaries of ripening and ripe and running females. These affected the advanced vitellogenic oocytes and occurred on the breakdown of the zona radiata (Fig. 3f). Virgin and resting females, with immature oocytes, were observed all year round (Fig. 2a, 3a,b).
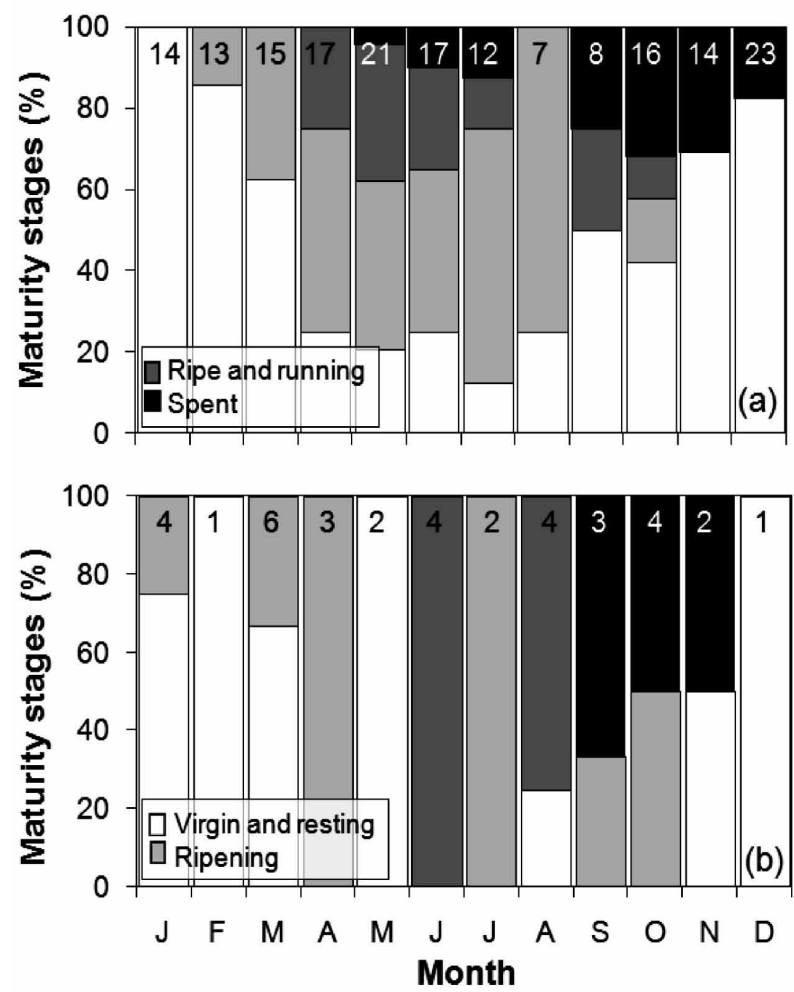

FIG. 2. - Monthly percentage of values of sexual stage for a) females and b) males of Mycteroperca fusca caught between January 2004 and December 2005 in waters of the Canary Islands. All calculated values of the index were grouped to show monthly variations over a single year. Number of fish sampled is shown for each month. 


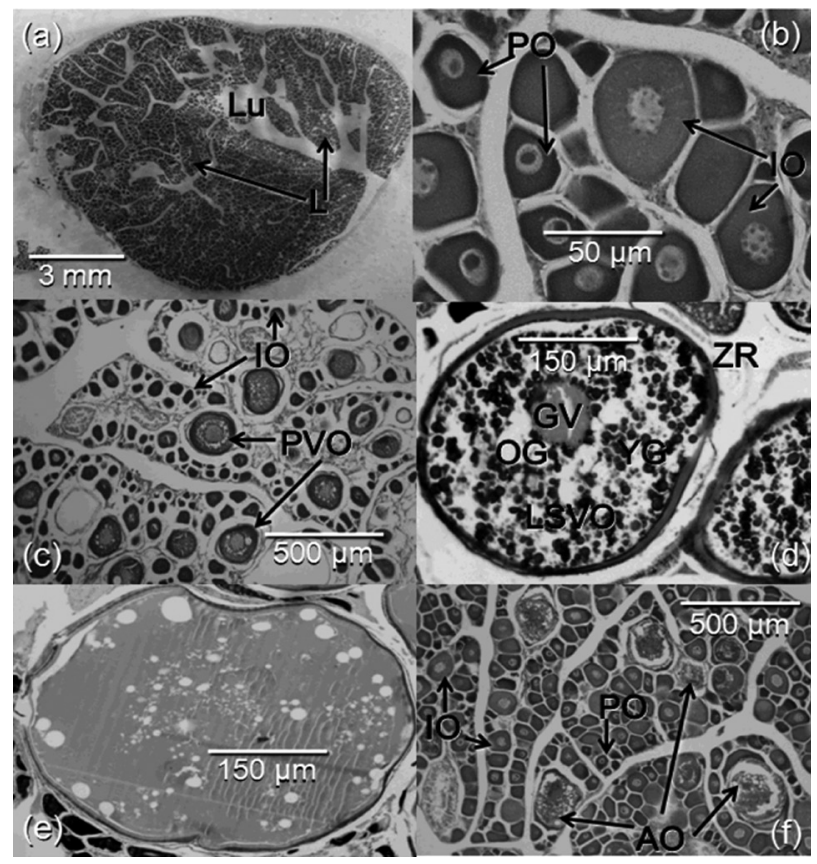

FIG. 3. - Transverse section through a resting ovary of Mycteroperca fusca showing: (a) ovarian structure characterized by a central lumen and the lamellas, and (b) high-power view of primary oocytes and immature oocytes; (c) Transverse section through a ripening ovary of Mycteroperca fusca showing primary oocytes, immature oocytes and oocytes in primary vitellogenesis characterized by scattered vacuoles in cytoplasm around the nucleus. (d) Transverse section through a ripe and running ovary of Mycteroperca fusca showing late secondary vitellogenic oocytes, with well-defined yolk globules throughout the cytoplasm and showing several small nucleoli situated along the periphery of the nucleus and the zona radiata, and (e) mature oocyte. Transverse section through a spent ovary of Mycteroperca fusca showing: (f) primary oocytes, immature oocytes and atretic vitellogenic oocytes. Lu: Lumen, L: lamellas, PO: primary oocytes, IO: immature oocytes, PVO: oocytes in primary vitellogenesis, LSVO: late secondary vitellogenic oocytes, GV: germinal vesicle, OG: oil globule, YG: yolk globule, ZR: zona radiata. AO: atretic oocytes.

As a consequence of the low number of males, ripening males were only observed between January and October, ripe and running males with spermatozoa visible as tiny, round cells with basophilic nuclei were only observed from June through to August, and spent males were observed between September and November (Fig. 2b, 4d).

The average value of the females GSI began to increase in February $(0.2 \%)$, reaching its maximum in June $(8.4 \%)$, followed by a downward pattern (Fig. $5 \mathrm{c})$. The males revealed a similar pattern but with maximum average values in June-July, at 3.5\% (Fig. $5 \mathrm{~d})$. The highest individual values of GSI were reached by the females (13.7\%) and males (4.4) in June (Fig. $5 a, b)$.

The length at sexual maturity (L50) was $335 \mathrm{~mm}$ TL. Of the females over $398 \mathrm{~mm}$ TL, 95\% were considered to be mature (Fig. 6a). The smallest-sized mature female was TLmin $=310 \mathrm{~mm}$ TL and the largest mature female was TLmax $=725 \mathrm{~mm}$ TL. The size at which $50 \%$ of the females transformed into males was

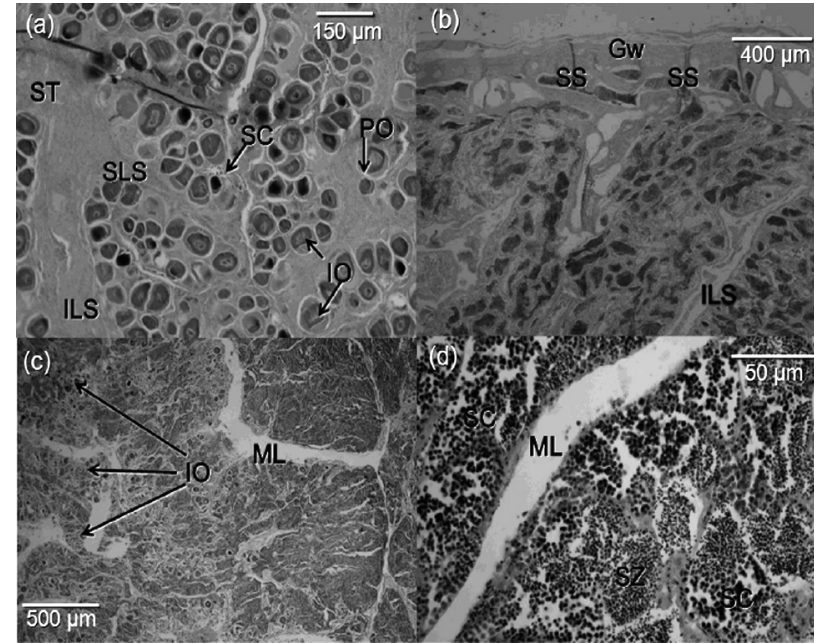

FIG. 4. - (a) Transverse section through a transitional gonad of Mycteroperca fusca showing primary oocytes, immature oocytes, and spermatocytes. (b) Transverse section through a teste of Mycteroperca fusca showing sperm sinus in the gonad wall. (c) Transverse section through a teste of Mycteroperca fusca showing immature oocytes and membrana-lined central cavities. (d) Transverse section through a teste of Mycteroperca fusca showing spermatocytes and spermatozoa. PO: primary oocytes, IO: immature oocytes, ML: membrana-lined central cavities, SC: spermatocytes; SP: spermatozoa; SS: Sperm sinus; GW: Gonad wall. ILS: Intra-lamellar stromal strand. SLS: Secondary lamellar stromal strand. ST: Stromal tissue.

$678 \mathrm{~mm}$ TL (Fig. 6b). The size range at which the process of sexual reversal took place was 428-725 $\mathrm{mm}$ TL. The range of overlap between the male and the female sizes was $41.1 \%$ of the maximum size observed for the species.

In all the males analyzed histologically $(n=36)$, a central cavity of membrane-lined central lumen-not used for sperm transport and a structural remnant of the ovarian lumen-was observed, and it was observed that the sperm sinuses were within the gonadal capsule rather than being presented as centrally located sinuses, typical of gonochoric species (Fig. 4a,b). Immature oocytes were observed in the testicular tissue (Fig. 4c). The ovarian structure was characterized by a central lumen with lamellation (Fig. 4a,d).

\section{DISCUSSION}

Protogynous hermaphroditism in the island grouper, $M$. fusca, is suggested by three features: the occurrence of at least one transitional individual; the presence of spermatic sinuses in the wall of male gonads; and the presence, in all analyzed testes, of a membrane- lined central lumen not used for sperm transport. In addition, sexual succession is supported by less specific features such as the lamellar organization of male gonads and a bimodal size/age frequency distribution, with males being significantly larger than females (Sadovy and Shapiro, 1987). As indicated in other studies, the most conclusive factors in determining the protogynous hermaphroditism in this species is the observation of specimens in transition between sexes, transitional 


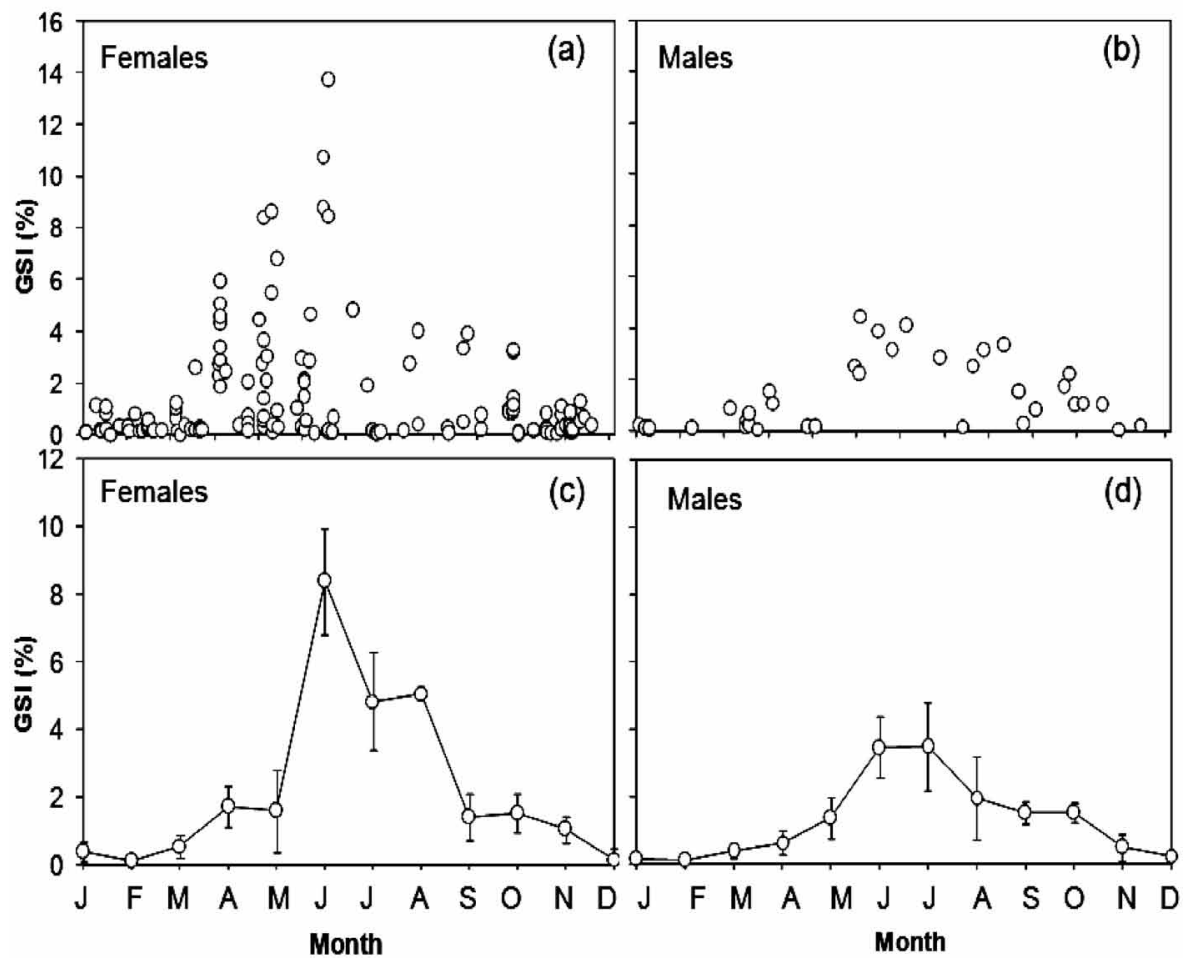

FIG. 5. - Individual and mean ( \pm S.D.) gonadosomatic index values for females and males of Myteroperca fusca caught between January 2004 and December 2005 in waters of the Canary Islands. All calculated values of the index were grouped to show monthly variations over a single year.

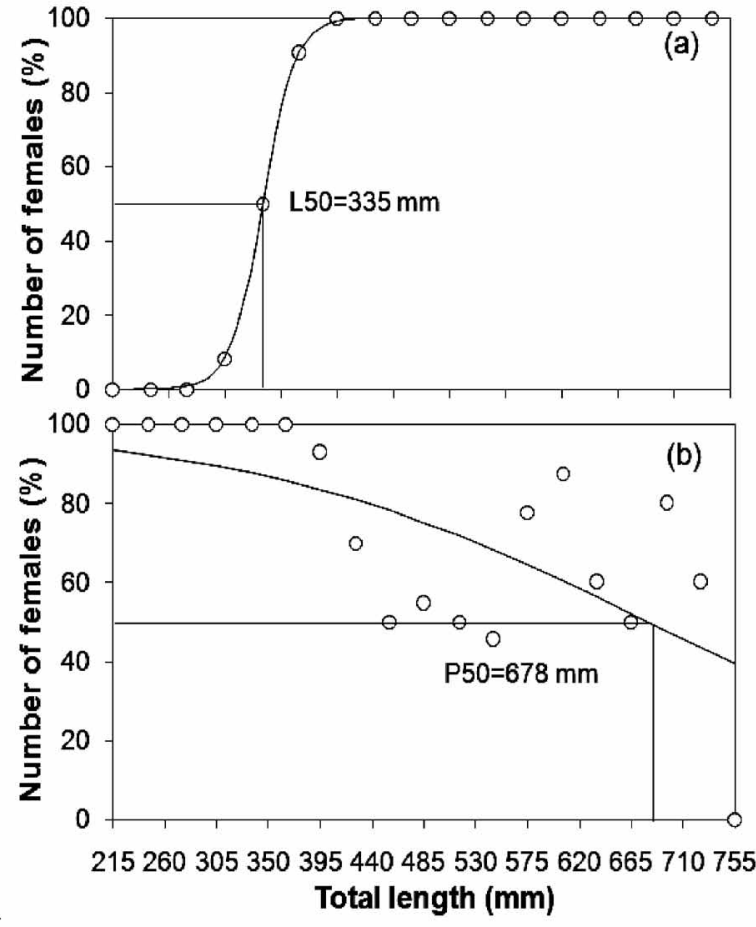

FIG. 6. - Percentage of mature females and maturity ogive (a), and percentage of females as a function of total length and the ogive of the female proportion for each size classes (b) for Mycteroperca fusca caught between January 2004 and December 2005 in waters of the Canary Islands. L50 indicates length at which fifty per cent of the specimens had become mature and P50 length at which 50\% of the females reverted to male. individuals with incipient nets of spermatagonium appearing on immature ovarian or functional structures (Sadovy and Shapiro, 1987; Sadovy and Colin, 1995; Brulé et al., 2003a). In the present investigation, only one specimen with these characteristics was found. This was probably due to the degeneration of ovarian tissue and the fact that the proliferation of testicular tissue is a very quick process (Brulé et al., 2003a). In this respect, Brulé et al. (2003a,b) only observed 6 and 2 individuals, respectively, in transition out of a total of over 800 specimens of Myteroperca bonaci (Poey, 1860) and another 400 of Mycteroperca microlepis (Goode and Bean, 1879). Similarly, Bullock and Murphy (1994) and Collins et al. (1997) indicated that transitional specimens have typically represented less than $1-2 \%$ of samples.

Protogynous hermaphroditism in $M$. fusca is in line with the pattern of sexual reversal described in other species of the genus, such as $M$. rubra in Mediterranean waters (Heemstra and Randall, 1999), Mycteroperca phenax Jordan and Swain, 1884 along the coast of the west-central Atlantic (Harris et al., 2002), M. bonaci (Brulé et al., 2003a), Mycteroperca intertitialis (Poey, 1860) (Bullock and Murphy, 1994;), and $M$. microlepis (Crabtree and Bullock, 1998; Collins et al., 1997; Brulé et al., 2003b) and Mycteroperca tigris (Valenciennes, 1833) (García-Arteaga et al., 1999) in the waters of the east Atlantic, which clearly reveal this as a characteristic of the genus.

The distribution of sexes by size and age demonstrated that males were not present in the sampled 
population until they reached $428 \mathrm{~mm}$ in length, which corresponds to 7 years of age (Bustos et al., 2009), and is above the size (398 mm) and age (5-6 years) of $95 \%$ female maturity (Bustos et al., 2009). Immature females were observed reaching a large size. This pattern has also been observed in other Mycteroperca species such as $M$. bonaci, $M$. venenosa, $M$. tigris and $M$. microlepis, and seems to be characteristic of the genus (Brulé et al., 2003 a,b; Tuz-Sulub et al. 2006).

Irrespective of the male pathway of development (males can develop from the juvenile phase or from adult females through sex change), the testes in protogynous serranids show the morphology of secondarily derived males, with a lamellar configuration and lumen of an earlier ovarian stage, and sperm sinuses within the gonadal wall (Sadovy and Liu, 2008). The results of the histological analysis and demographic structure of the specimens for the north-west coast of Africa are consistent with a monandric protogynous sexual pattern for $M$. fusca. Monandric protogynous characteristics have been observed in $M$. bonaci and M. microlepis in the waters of the Gulf of Mexico (Brulé et al., 2003a, b). The size structure by sex is determined by the nature of the sexual reversal. In this respect, Sadovy and Shapiro (1987) indicated that the sex-ratio of the protogynous species is biased towards the females. This predominance of females over males has also been noted in various other highly-fished species in the genus, such as M. bonaci (Crabtree and Bullock, 1998; Brulé et al., 2003a), M. microlepis (Collins et al., 1997; Brulé et al., 2003b), M. phenax (Harris et al., 2002), M. tigris (García-Arteaga et al., 1999) and Mycteroperca venenosa (Linnaeus, 1758) (García-Cagide and García, 1996). This predominance is seen to be accentuated through the pressure of fishing which removes longest-living individuals (Collins et al., 1997). The presence of females in the higher size categories implies that the conversion is not essential in all individuals (Sadovy, 1996). This is also in line with the broad range of sizes at which sexual reversal is found, and the large size at which $50 \%$ of the females reversed to males. The role of large, old females is not well understood, but may be a reflection of successful reproduction (as females) throughout their lifetimes (Sadovy, 1996). Large, old females with a female-male difference in size $<10 \mathrm{~cm}$, have been observed in other Mycteroperca species and seem to be a characteristic of the genus (Brule et al., 2003 a,b; Tuz-Sulub et al. 2006).

The values of bias in the sex-ratio, with a low number of males in the population, are similar to those observed by Brulé et al. (2003a) for M. bonaci, and by Brulé et al. (2003b) for M. microlepis. Similarly, Collins et al. (1987), and Coleman et al. (1996) indicate that the heavy imbalance towards females observed in some species within the genus is partly due to the pressure of fishing to which they are subject, given that the fishing activity eliminates the longest-living specimens.
The reproductive period of the Canarian species M. fusca is broad, with a larger proportion of mature specimens found in the spring and summer months. The reproductive process is initiated when the water temperature increases from its lowest values $\left(18^{\circ} \mathrm{C}\right.$, February) to its highest values $\left(24-26^{\circ} \mathrm{C}\right.$, AugustSeptember). A prolonged spawning period suggests the existence of favourable environmental conditions for spawning and development of larvae, as has been observed in the cases of $M$. bonaci and $M$. microlepis (Brulé et al., 2003a,b). In determining the reproductive period, Sadovy (1996) indicated that it must be considered as the month when $50 \%$ or more of the females analyzed are in vitellogenesis. According to this criterion, the central period of spawning is restricted to the months from April to July, inclusive.

Mycteroperca fusca reaches maturity at a large size (approximately 50\% of its maximum size as observed), which is characteristic of specialist species. This coincides with what has been described in other species of the genus such as M. venenosa (GarcíaCagide and García, 1996), M. intertitialis (Bullock and Murphy, 1994) M. microlepis (Brulé et al., 2003b) and M. bonaci (Brulé et al., 2003a), in which maturity is reached at between $50 \%$ and $65 \%$ of the maximum size described for the species. This suggests that maturity is closely linked to the body size at which the organism has sufficient reserves to survive the stress caused by the reproductive process.

The protogynous hemaphroditism described for the species results in an imbalance towards females, with males less abundant and restricted to those of older age and larger size. This inequality in distribution leads to differentiated death-rates due to fishing between the sexes (Alonzo et al., 2008). In the Canary Islands, where conservation legislation on fisheries exists, only a minimum size limit has been implemented for the target species without biological information on size at maturity, or on the sexual inversion process in the species. In the case of $M$. fusca, this minimum size regulation is of limited benefit because the minimum length at which fish may legally be kept is lower than the length at maturity of females. In addition, the release of these fish, once captured, is of dubious benefit as they often suffer from barotrauma when brought to the surface from depths of more than $30 \mathrm{~m}$ and will not survive when released.

In the Canary Islands, the state of the population of $M$. fusca is directly linked to the high degree of human pressure on the species (Tuya et al., 2005; Bustos 2009). This species is particularly vulnerable to overfishing due to the reduction in its potential reproductive capacity caused by the decrease in the number of males in the population. The data given by Hunstman and Schaaf (1994) suggest that protogynous species suffer a drastic reduction in their reproductive capacity even at moderate levels of exploitation because their low age of maturity is not sufficient to compensate for the reduction in reproductive capacity due to the de- 
crease in male abundance. All of this suggests that the intense exploitation of the larger size groups may be at least partly responsible for the current low levels of abundance of the population. A possible option, which could improve the situation for $M$. fusca and for all fish species of the benthic community, would be to protect part of the spawning stock and the recruits in marine reserves, which would encompass the coastal inshore areas with good algal vegetation or seagrass beds, and to establish a minimum fishing depth of $30 \mathrm{~m}$ to protect the nursery areas located in shallow areas (Bustos, 2009).

\section{ACKNOWLEDGEMENTS}

This study was funded by the Government of the Canary Islands. We wish to acknowledge the criticisms of two anonymous reviewers and the comments and suggestions of Dr. M. Pilar Olivar, which helped to improve the manuscript.

\section{REFERENCES}

Alonzo, S.H., T. Ish, M. Key, A.D. MacCall and M. Mangel. 2008. The importance of incorporating protogynous sex change into stock assessments. Bull. Mar. Sci., 83(1): 163-179.

Brulé, T., C. Déniel, T. Colás-Mafurro and M. Sánchez-Crespo. 1999. Red grouper reproduction in the southern Gulf of México. Trans. Am. Fish. Soc., 128: 385-402.

Brulé, T., X. Renán, T. Colás-Marrufo, Y. Hauyon and A.N. TuzSulub. - 2003a. Reproduction in the protogynous black grouper (Mycteroperca bonaci (Poey)) from the southern Gulf of Mexico. Fish. Bull., 101: 463-475.

Brulé, T., C. Deniel, T. Colás-Marrufo and X. Renan. - 2003b. Reproductive biology of gag in the southern Gulf of Mexico. $J$. Fish Biol., 63: 1505-1520.

Bullock, L.H. and M.D. Murphy. - 1994. Aspects of the life history of the yellow grouper, Mycteroperca interstitialis, in the Gulf of Mexico. Bull. Mar. Sci., 55: 30-45.

Bustos, R. - 2009. Estudio de los parámetros biológicos del abade Mycteroperca fusca (Lowe, 1836) en aguas del archipiélago canario y situación de sus poblaciones en la isla de El Hierro y la reserva marina de la isla de La Graciosa y de los islotes del norte de Lanzarote. Ph.D. thesis. Univ. Las Palmas de Gran Canaria.

Bustos, R., A. Luque and J.G. Pajuelo. - 2009. Age estimation and growth pattern of the island grouper, Mycteroperca fusca (Serranidae) in an island population on the northwest coast of Africa. Sci. Mar., 73(2): 319-328.

Coleman, F.C., C.C. Koenig and L.A. Collins. - 1996. Reproductive styles of shallow-water grouper (Pisces: Serranidae) in the eastern Gulf of Mexico and the consequences of fishing spawning aggregations. Env. Biol. Fish., 47: 129-141.

Collins, M.R., C.W. Waltz, W.A. Roumillat and D.L. Stubbs. 1987. Contribution to the life history and reproductive biology of gag, Mycteroperca microlepis (Serranidae), in the South Atlantic Bight. Fish. Bull., 85: 648-653.

Collins, L.A., A.G. Johnson, C.C. Koenig and M.S. Baker. - 1997.
Reproductive patterns, sex ratio, and fecundity in gag, Mycteroperca microlepis (Serranidae), a protogynous grouper from the northeastern Gulf of Mexico. Fish. Bull., 96: 415-427.

Crabtree, R.E. and L.H. Bullock. - 1998. Age, growth and reproduction of black grouper, Mycteroperca bonaci, in Florida waters. Fish. Bull., 97: 735-753.

García-Arteaga, J.P., L.M. Sierra and R. Claro. - 1999. Biología del bonací gato, Mycteroperca tigris (Pisces: Serranidae) en la plataforma de SW de Cuba. II. Alimentación, edad y crecimiento. Rev. Invest. Mar., 20: 1-3.

García-Cagide, A. and T. García. - 1996. Reproducción de Mycteroperca bonaci y Mycteroperca venenosa (Pisces: Serranidae) en la plataforma Cubana. Rev. Biol. Trop., 44: 771-780.

Harris, P.J., D.M. Wyanski, D.B. White and J. Moore. - 2002. Age, grow and reproduction of scamp, Mycteroperca phenax, in the south-western north Atlantic, 1979-1997. Bull. Mar. Sci., 70: 113-132.

Heemstra, P.C. - 1991. A taxonomic revision of the eastern Atlantic groupers (Pisces: Serranidae). Bol. Mus. Mun. Funchal, 43: 5-71.

Heemstra, P.C. and J.E. Randall. - 1999. Serranidae. In: K.E. Carpenter and V.H. Niem (eds.), FAO Species Identification Guide for Fishery Purposes, pp. 2442-2547. FAO, Rome.

Hunstman, G.R.D. and W.E. Schaaf. - 1994. Simulation of the impact of fishing on reproduction of protogynous grouper, the graysby. N. Am. J. Fish. Manag., 14: 41-52.

Moe, M.A. - 1969. Biology of the red grouper Epinephelus morio (Valenciennes) from the eastern Gulf of Mexico. Flo. Dep. Nat. Resour. Mar. Res. Lab. Prof. Pap. Ser., 10: 95 pp.

Rhodes, K.L. and Y. Sadovy. - 2002. Reproduction in the camouflage grouper (Pisces: Serranidae) in Pohnpei, Federate States of Micronesia. Bull. Mar. Sci., 70: 851-869.

Sadovy, Y.-1996. Reproduction of reef fishery species. In: M.V.C. Polunin and C.M. Roberts (eds.), Reef Fisheries, pp. 15-59. Chapman and Hall, New York.

Sadovy, Y. and P.L. Colin. - 1995. Sexual development and sexuality in the Nassau grouper. J. Fish Biol., 46: 961-976.

Sadovy, Y. and M. Liu. - 2008. Functional hermaphroditism in teleosts. Fish Fish., 9: 1-43.

Sadovy, Y. and D.Y. Shapiro. - 1987. Criteria for the diagnosis of hermaphroditism in fishes. Copeia, 1: 136-156.

Shapiro, D.Y. - 1984. Sex reversal and sociodemographic processes in coral reef fishes. In: G.W. Potts and R.J. Wootton (eds.), Fish Reproduction: Strategies and Tactics, pp. 103-118. Academic Press, London.

Shapiro, D.Y., Y. Sadovy and M.A. McGehee. - 1993. Periodicity of sex change and reproduction in the red hind, Epinephelus guttatus, a protogynous grouper. Bull. Mar. Sci., 53: 1151-1162.

Sokal, R.R. and F.J. Rohlf. - 1995. Biometry: The Principles and Practice of Statistics in Biological Research. W.H. Freeman, New York.

Tuya, F., P. Sánchez-Jerez and R.J. Haroun. - 2005. Population of inshore serranids acrosss the Canarian Archipelago: Relationships with human pressure and implications for conservation. Biol. Conserv., 12: 13-24.

Tuz-Sulub, A., T. Brulé, K. Cervera-Cervera and J.C. EspinozaMendez - 2006. Evidence for sexual dichromatisms in spawning aggregations of yellowfin grouper Mycteroperca venenosa and tiger grouper Mycteroperca tigris from the southern Gulf of Mexico. J. Fish Biol., 69: 1744-1755.

Scient. ed.: M.P. Olivar.

Received June 3, 2009. Accepted January 14, 2010.

Published online June 7, 2010 